\title{
Commercial Real Estate Prices and Stock Market Returns: An International Analysis*
}

\author{
Daniel C. Quan \\ Department of Finance \\ University of Texas at Austin \\ Austin, TX. 78712-1179 \\ Sheridan Titman \\ Collins Professor of Finance \\ Wallace E. Carroll School of Management \\ Boston College, Chestnut Hill, MA. 02167
}

First Draft - January, 1996

May, 1996

\begin{abstract}
*The authors gratefully acknowledge the support of the Real Estate Reseach Institiute. We would also like to thank Jones Lang Wootten, BoMa, FRC Canada and Morgan Stanley International for providing us with our data. An earlier version was presented at the 1996 Homer Hoyt meeting. The first author also benefitted from U. of Texas's summer research grant.
\end{abstract}


The movement towards the "globalization" of institutional investments necessitates an understanding of the historical relationship between international commercial real estate price changes and stock returns. Existing studies have focused on the time-series of stock and real estate returns using data from a single country, like the US. By necessity, these studies examine returns and price changes over short intervals creating a bias when property values are smoothed from year to year. This paper examines the relation between stock returns and changes in property values and rents on data from 17 different countries. Although we find no relation between real estate values and rents and stock returns in the U.S., we find significant relations in a number of different countries. When the data is pooled, we find a very strong relation between stock returns and both value changes and changes in rental rates. 


\section{INTRODUCTION}

Institutional investors have expanded their scope of investments in two important ways during the past 15 years. They have become more active in the direct purchase of real estate and they have become more global in their approach to investing. However, except for a few notable exceptions, U.S. institutions tend to stay close to home when it comes to real estate investments.

The increased presence of real estate and foreign stocks in the portfolios of institutions may have been motivated in part by academic studies that suggest that covariances between U.S. stocks and both foreign stocks and U.S. commercial real estate are quite low, indicating that the latter asset classes provide diversification to portfolios invested primarily in U.S. stocks. The reluctance to purchase foreign real estate directly is probably due to the increased expenses and the information prob-

lems associated with purchasing real property outside of the U.S.. In addition, there has been no research that we are aware of that examines the risk/return trade-offs involved in such investments.

In this paper, we take some initial steps towards understanding the relation between commercial real estate returns and stock returns in an international context. The analysis examines the relation between commercial real estate returns and stock returns in 17 different countries. These include the largest industrialized economies as well as some of the smaller economies in Asia's emerging market. In addition to providing valuable information to institutional investors, we think this study has the potential to shed light on important issues regarding the relation between changes in commercial real estate prices and stock returns more generally. In particular, by examining a larger set of countries, we have sufficient data to examine somewhat longer holding period price changes and thus estimate regressions that we think better 
account for the smoothed nature of the commercial real estate time series.

Our investigation extends earlier studies which examine the relation between stock returns and price changes of commercial real estate in individual countries. As we mentioned above, academic research suggests that in the US, real estate returns and stock returns are not highly correlated and that the relation may in fact be negative. Using annual US data from 1947 to 1982, Ibbotson and Siegel (1984) found real estate's correlation with S\&P stocks to be -.06 whereas Hartzell (1986), using quarterly data from 1977 to 1986, estimated the correlation to be -.25. Worzala and Vandell (1993), using the Frank Russell Index and more recent quarterly data from 1980 to 1991 estimated the correlation to be -.0971. Geltner (1993), applying a "de-smoothing" procedure which alters the volatility of the real estate return index, reported a correlation of .3. With respect to evidence from other countries, Lim (1992), using a quarterly transactions based index, estimated the correlation for Singapore to be .43. Worzala and Vandell (1993) estimated the UK real estate correlation with stock returns to be .039 whereas Geltner (1994), once again using a "de-smoothing" procedure reported a .38 correlation with UK data ${ }^{1}$. Although Stone and Ziemba (1993) documented a strong relationship between Japanese land prices and stock market performance, their study did not include commercial investment grade properties.

\section{Why Should Commercial Real Estate Returns be Related to Stock Re- turns?}

Real estate prices and stock prices are both affected by the level of economic activity, by interest rates and by the cost of labor. We would expect that the level of economic activity would have a positive effect on both real estate and stock prices,

\footnotetext{
${ }^{1}$ To the best of our knowledge, the only other multi-country study is Goetzmann and Watcher (1995) which only focused on rents.
} 
causing the two time-series to move together. However, other factors can conceivably cause the two time-series to be negatively correlated. For example, stock prices may increase because of increased investment opportunities in an economy's corporate sector. This increase in investment opportunities could in turn lead to increases in real interest rates, which could reduce the value of commercial buildings even if their rental prices increase. Changes in the cost of labor could also induce a negative relation between stock prices and commercial real estate values. For example, foreign competition may lead to decreases in domestic wage rates which in turn lead to increased corporate profits and higher stock prices. However, if wage rates in the building sector also decrease, construction costs decline, and the value of commercial real estate will fall. Hence, changing labor costs can lead to negative correlations between commercial real estate values and stock prices.

One can plausibly argue that the factors that induce a negative relation between real estate values and stock prices are more relevant for the larger more developed economies in Europe, North America and Japan. For example, some have argued that one of the contributors to the recent bull markets in the U.S. was reductions in real wage rates caused by technological changes and foreign competition. One might also argue that factors that contribute to a positive relation between stock and real estate values are less important in countries in large developed countries where individuals are relatively mobile. Increased economic activity in the U.S. may have a relatively small effect on the U.S. office market both because of supply responses and because firms can relocate to less expensive areas if prices in New York and other major cities become too expensive.

In the smaller Asian countries, like Singapore and Hong Kong, the factors inducing a negative relation between stock returns and real estate prices may be less important. First, the stock market flucuations in these economies seem to be due more to demand side effects (e.g., increased trade with China) than cost side effects (e.g., reduced labor 
costs). Second, these small, relatively open economies, experience increased capital inflows when their investment opportunities improve. Hence, the increased demand for office space that corresponds to an economic boom is not likely to be offset by higher interest rates. (This is especially true in Hong Kong where the interest rates are essentially the same as the U.S. rates because of the fixed exchange rate between Hong Kong and U.S. dollars.) Finally, it should be noted that people are somewhat less mobile in these smaller less developed economies. A money management firm in Manhattan might be willing to move to Connecticut if property prices in New York got too high, which would dampen the increase in the price of prime New York office

space. However, a similar firm would find it much more difficult to move off Hong Kong island in a similar circumstance. The above arguments suggest that we might expect to find a stronger positive relation between stock returns and commercial real estate values in the smaller Asian countries than we would find in Japan, North America and Europe.

\section{The Serial Correlation of Commercial Real Estate Price Changes}

An investigation of the relation between real estate price changes and stock returns is greatly complicated by the nature of the real estate data. The evidence provided in Table 1 (described in detail in the next section) indicates that both the yearly price changes and the yearly rental changes are serially correlated. These serial correlations play an important role in our research design and thus warrant further discussion.

There are a number of possible reasons why the real estate capital indexes are serially correlated. First, all of the indexes include appraised values. Appraised values are likely to be serially correlated since appraisers, having limited information, must base their valuations on sales occuring in the past, (see Quan and Quigley (1991) for further discussion of this). Appraisal lags of this sort can induce serial correlation in rental as well as capital value indexes. 
Observed rental prices may be further smoothed by variations in tenant improvements. For example, in a very hot market, owners may be reluctant to raise rents too high, and may instead cut tenant improvements. When demand is low, rather than drastically cutting prices, owners may attract tenants with very generous tenant improvements. If the rental index ignores the changing levels of tenant improvements, these changing levels of tenant improvements can induce positive serial correlation in rental indexes.

A second explanation for the serial correlation has to do with the fact that in a downturn the prices of different buildings are likely to fall different amounts and the timing of when a particular building is sold is determined in part by the amount that its price changes. Consider, for example, a situation where building values fall $20 \%$ on average; however, some of the buildings fall only $10 \%$, from $\$ 50$ million to $\$ 45$ million, and others fall $30 \%$, from $\$ 50$ million to $\$ 35$ million. If the buildings that fall in price the least are the first to sell, then we will observe what appears to be an initial $10 \%$ drop in real estate values followed by a subsequent $30 \%$ fall. In other words, it will look like prices are serially correlated.

To understand why the buildings that drop in price the most are less likely to be sold during the initial downturn consider the situation facing someone who bought a building for $\$ 50$ million with a $\$ 40$ million loan. If the building's value falls to $\$ 35$ million, the owner will have negative equity, and may thus have no incentive to sell the building since the proceeds of the sale go completely to the lender. The owner's claim, in this case, resembles an option on the building. The value of that option is still valuable even though the owner has negative equity; if the building's value eventually goes up, the owner's claim will be back in the money. By selling the building, the owner is throwing away what could be a valuable option. In contrast, those owners with buildings that fell in price to $\$ 45$ million give up less in option value when they sell, and hence, will not be as averse to selling the property. 
Part of the observed positive serial correlation in the price changes of appraised real estate indexes may also be due to what we call a lead-lag effect. For example, an index such as the Frank Russell index, the most commonly cited real estate index, would show positive serial correlation if price changes in the mid-west cities lagged price changes on the east and west coasts. Aggregate price increases at date t, generated from price increases on the coasts, would then be expected to be followed by aggregate price changes at date $t+1$, generated because of the lagging price increases in the mid-west. If this sort of lead-lag effect was the primary cause of the positive serial correlation, we would expect to find less serial correlation in a place like Hong Kong, which is consistent with our findings.

We would expect this lead-lag effect to have a greater effect on rental indexes than on capital value indexes. To the extent that the indexes are reasonably accurate, and real estate markets are efficient, there is likely to be very little lead-lag in the purchase market. If demand for Boston office space lags the demand for New York office space by one year, then rents in Boston should also lag rents in New York by one year. However, information about price increases in New York should immediately be incorporated into Boston prices if the markets are efficient. Otherwise, real estate investors could earn excess profits by buying Boston property following price increases in New York.

The above arguments provide explanations for why real estate indexes may be serially correlated when the true underlying process generating transaction prices are serially uncorrelated. However, it is also possible that the actual transaction values might be serially correlated. This would occur, for example, if real estate investors were liquidity constrained, and were thus able to buy more real estate following price increases that lessened their constraints and were forced to sell real estate following price declines. The current situation in Southern California may offer an example of serial correlation on the down side. Anecdotal evidence suggests that following 
unfavorable shocks (e.g., defense cuts, riots, earthquakes etc.) which caused initial price declines, there were further declines due to the fact that many of the investors with knowledge of Southern California real estate were financially wiped out. These investors have been replaced, with a lag, by new investors that require higher expected rates of appreciation, and thus lower prices, to compensate for their lack of expertise and information. Many of these investors currently have highly levered positions. If commercial real estate prices do increase in the future, then these investors will have additional borrowing capacity that will enable them to buy additional properties which can lead to further price increases.

It should be noted that the above scenario is not likely to generate positive serial correlation in the rental indices. Indeed, these considerations could conceivably lead to negative serial correlation since positive shocks to rental demand can lead to shortterm shortages that are later corrected with supply responses.

\section{DATA DESCRIPTION AND SUMMARY STATISTICS}

We have compiled a database of capital value and rental indexes from various sources of prime office market properties for specific cities in 17 countries. The countries (and cities) are the Netherlands (Amsterdam), Spain (Madrid), Germany (Dusseldorf, Frankfurt, Hamburg, Munich), France (Paris), Italy (Milan), U.K. (London), Australia (all cities index), Malaysia (Kuala Lumpur), Japan (Tokyo), Taiwan (Taipei), Indonesia (Jakarta), Singapore (Singapore), Hong Kong (Hong Kong), Canada (all cities index), and the U.S. (all cities index). ${ }^{2}$ For some countries, data is available from 1977 to 1994 while 2 countries only have data from 1987 to 1994 . With the exception of Malaysia and Indonesia, we used Morgan Stanley's Capital

\footnotetext{
${ }^{2}$ Our data sources are Jones Lang Wootten (for the Netherlands, Spain, Germany, France, Italy, U.K., Malaysia, Japan, Taiwan, Indonesia, Singapore, Hong Kong), Russell-NCREIF (US), FRC Canada (Canada), and BOMA (Australia).
} 
International stock return indexes for all of our 17 countries for our measure of stock market performance. The Morgan Stanley indexes are 100\% market cap weighted indexes with gross dividends of selected stocks traded in each country's exchanges. For Malaysia, we used the Kuala Lumpur Composite Index which is a capitalizationweighted index of 100 stocks listed in the Kuala Lumpur Stock Exchange and for Indonesia we used a capitalized-weighted index of all stocks listed on the Jakarta Stock Exchange.

Table 1 provides a brief description of our data. It provides the time period over which we have data for the 17 countries along with information on their average stock returns, capital appreciation of the real estate and percentage changes in commercial rents during these time periods. The table also reports the first order serial correlation of the price changes and rental rate changes for these time series. As in any study constrained by the availability of historical data, our sample may not capture relationships that vary over the business cycle and our results may therefore be sample specific. Since the common period for all 17 countries is 1988-1994, a period when most stock markets did quite well, our results should be interpreted with some caution.

With the exception of the US, Canada and Australia, all data were obtained from Jones Lang Wootton (JLW). From conversations we had with JLW, their estimates of capital and income values arise from a consensus opinion about the price and rents paid for prime commercial properties within their respective markets based on market transactions. The group is polled about the prevailing price and lease terms for prime commercial real estate. Although this method can be loosely categorized as an "appraisal" based approach, it is important to note that it is dramatically different from the way return indexes are calculated for Australia, Canada and the US where institutional investors are polled about the value of the property in their real estate portfolios. We believe that in the latter case the tendency for artificial smoothing 
may be greater, particularly for properties with long-term leases. ${ }^{3}$

This belief is partially supported by the autocorrelation parameters of capital values in Table 1a where, with the exception of Belgium and Japan, the three country wide (rather than city) indices exhibited the highest serial correlation. The higher serial correlation in these three countries is also consistent with the lead-lag argument described earlier since the data in these countries come from geographically dispersed regions rather than in single cities as is the case for most of the other countries.

From Table 1a, it is evident that there is considerable variation in the mean annual price changes between countries in the 1988 to 1994 period. Hong Kong and Indonesia were the best performers for capital values expressed in their domestic currencies, and when we measure price changes in a common currency, specifically US\$, Hong Kong and Singapore showed the best performance. In contrast, the commercial real estate in Canada, Japan, New Zealand, the U.K. and the U.S. realized negative price changes over this period. The average mean price changes were 5.19 and 5.85 for all 17 countries when expressed in domestic currency and US\$ respectively.

The correlation matrices of real estate capital and income are provided in Tables $1 \mathrm{~b}$ and 1c respectively. All correlations are calculated with prices expressed in domestic currencies so the correlations are not due to exchange rate changes. ${ }^{4}$ We see from 1b that Australia, Canada, Japan, New Zealand and the UK real estate markets are positively correlated with the US's market whereas Hong Kong and Malaysia reveal

\footnotetext{
${ }^{3}$ The Frank Russell Index for the US, Canada and Australia, is constructed from surveys of investment grade commercial real estate holdings from large tax exempt institutions. Each participating institution submits quarterly appraisals of property values and data on income generated for each property. For the US, as of the 4th quarter of 1995, the sample includes 2322 properties estimated at $\$ 47.8$ billion.

${ }^{4}$ If, for example, the dollar depreciates relative to the currencies of a number of other countries in our sample, the dollar denominated returns in these countries are likely to increase. This induces positive correlation in the dollar denominated returns.
} 
large negative correlations.

\section{Cross-Sectional Tests}

Another possible explanation for the low correlation reported in other international studies is the periodicity of their data. Most of the previously cited studies reported quarterly or annual correlations. Our discussion of the serial correlations in section 1.2 suggests that quarter to quarter changes in real estate indexes may be misleading indicators of the actual price changes. In particular, year to year as well as quarter to quarter price changes are likely to understate commercial real estate's true volatility.

A number of empirical studies have suggested that stock returns are excessively volatile over short intervals ${ }^{5}$. Thus studies utilizing quarterly or annual data face the unfortunate task of attempting to detect a relationship between excessively volatile and frequently traded stock indexes with artificially smoothed real estate indexes. Thus a sensible alternative is to compare stock and real estate returns for long holding periods using all 17 countries in our sample. A longer measurement interval reduces the effect of smoothing on the real estate in the real estate index as well as the excess volatility of the stock market index.

The longest common period that price changes can be calculated in our database is from 1988 till 1994. We calculated the change in value for both stock and real estate for the 17 countries over this period. These 17 observations can be interpreted as the total capital returns that an investors would have realized if he had made an investment in 1988 and liquidated in 1994 . With these 17 observations, we regressed changes in real estate value on stock price changes from 1988 to 1994 with all values expressed in domestic currency. This specification resulted in an $R^{2}$ of .5902 with the following estimates:

\footnotetext{
${ }^{5}$ See Shiller (1981) and Fama and French (1988)
} 


$$
R E=-30.28+.5995 * \text { Stock }
$$

The t-statistics for the stock coefficient was 4.648. These results indicate a strong relationship between stocks and real estate which is pervasive across the 17 countries. Because of our limited sample of countries, the normality assumption may not be justifiable in the above regression. We computed the nonparametric Spearman's rho statistic. The value of .6863 was significant at the $99.5 \%$ confidence level; thus we strongly reject the hypothesis that the two variables are independent ${ }^{6}$. Taken together, this provides strong evidence of a positive relationship between stock and return price changes, a relationship not previously detected in prior studies ${ }^{7}$.

\section{Time-Series Tests}

The cross-sectional regressions estimated in the previous section establishes that there is indeed a positive relation between stock returns and real estate price changes. However, as we discussed earlier, we do not believe this relation should be the same in all countries. In this section, we present time-series estimates that allow us to measure the relation between stock prices and real estate prices for each of the 17 countries individually. To be consistent with earlier work, we start by estimating simple univariate regressions of real estate price changes and rental changes on stock returns. These regressions are summarized in Table 2. Because of the smoothed

\footnotetext{
${ }^{6}$ The results were very similar when all values were expressed in U.S. currencies. The $R^{2}$ was .5029 and the stock coefficient and t-statistic were .6745 and 3.89 respectively and the Spearman rho statistic was .7181 .

${ }^{7}$ We performed the same regressions using rents in both domestic and U.S. currencies. The fits were worst than those with capital value in both cases. In domestic currency, the $R^{2}$, stock coefficient and its t-statistic was $.2383, .3347$ and 2.166 respectively whereas when denominated in U.S. currency, the corresponding values were $.2589, .4356$ and 2.289 .
} 
nature of the real estate time series, these regressions are misspecified and are not the focus of our investigation. We are more interested in a second set of regressions which include a lagged stock return term which partially accounts for the fact that the real estate indices are smoothed.

Specifically, we estimate the following regression:

$$
R E=\beta_{0}+\beta_{1} * \text { Stock }+\beta_{2} * \operatorname{Stock}(-1)+u
$$

These regressions are reported in Table 3.

The estimated relation between stock returns and changes in both real estate prices and rental rates do not exhibit a clear pattern when we look from country to country. For example, consistent with the earlier cited studies, we find no significant relation between stock returns and real estate price changes in the United States. However, in countries like the U.K., Japan and a number of smaller countries, we find that stock returns have a strong positive effect on real estate values as well as on rental rates. In most of the other countries we find a positive relation between stock returns and real estate price changes, but because our time-series are relatively short and volatile, the relations are generally statistically insignificant.

There are two weaknesses of the tests presented in Table 3. The first is that the individual tests, having very few observations, lack power. We observe an economically significant relation between stock returns and real estate price changes in a number of countries, but the relation is not statistically significant in many of the countries because the regressions have very little power. The second problem has to do with multiple comparisons. For example, we find that 5 out of the 17 countries have a statistically significant (at the 10\% level) relation between stock returns and changes in real estate value. However, we are likely to find a statistical relation in some countries between any two time series just by chance if we look at a enough countries, and we haven't sufficient degrees of freedom to formally test whether or 
not finding 5 out of 18 significant coefficient estimates is more than we would expect by chance.

To solve the multiple comparison's problem and enhance the power of our tests, we pool the cross-section and time-series data into a single panel and estimate equation (1) with a fixed effects regression that accounts for country as well as year effects. This is done by adding country dummy variables as well as year dummy variables to a regression that constrains the coefficients of the stock return variables to be fixed across both countries and time. These fixed effects regressions are run for the entire sample as well as for separate subsamples consisting of Asian/Pacific and European countries.

Table 4 presents the results of the fixed effects regressions. The results in Table 4, which provides the estimates for the entire sample, provides stronger evidence of a positive relation between stock returns and real estate prices. In addition to a stronger relation between lagged stock returns, the regressions reveal a significant contemporaneous relation. In order to test whether the relation between real estate and stock returns is region specific, we separately estimate fixed effects models for Europe and Asia/Pacific region. These regressions are presented in Table 5. The results indicate that the relation between real estate and stock returns is quite strong in Asia, but fairly weak in Europe.

For each of the specifications contained in Tables 4 and 5, we tested for the joint significance of the time dummy variables as well as the country dummy variables. We find that there is a time effect over in our sample period which means that there is indeed a common global factor generating real estate prices. However, we could not reject the hypothesis that the average price changes in the different countries are the same.

It it important to note that the inclusion of the lagged stock returns variable reduces the serial dependence of the residuals in the time-series regressions, which suggests 
that the reported t-statistics are reasonably reliable. We tested for the presence of serial dependence within our panel estimation framework by calculating an augmented Durban Watson statistics in the above specification ${ }^{8}$. Our statistic value was 1.139 which was only marginally significant at modest confidence levels. We also considered the possibility that the autocorrelation parameter may differ between countries. Our results are robust with respect to this more general specification. Thus it appears that the inclusion of the lagged stock term purged our data of the serial dependence.

\section{CONCLUSION}

This paper examines the relation between stock returns and real estate values in 17 different countries. In contrast to existing evidence from the U.S., we find that in aggregate, there is a strong positive relation between real estate values and stock prices. The strong positive relation is found in cross-sectional as well as time-series regressions. The time-series evidence indicates that the positive relation is mainly due to countries in the Asia/Pacific region, however, there is also a positive relation between stock and real estate prices in selected European countries.

Future research is needed to determine why the relation between real estate and stock prices are significant in some countries but not others. We have suggested various reasons why this relation might differ from country to country, but have not yet come up with a way to test our hypotheses. While it would certainly be more interesting if the differences were due to fundamental differences in the structures of the economies, it is also possible that the differences in the estimated relations may be due to differences in the quality of the real estate appraisals across countries. However, it is noteworthy that four of the countries with the most reliable data, the U.S., Australia, Canada and Hong Kong, all had insignificant relations between stock

\footnotetext{
${ }^{8}$ We employed an augmented Durban-Watson statistics for panel data for unbalanced panels as suggested by Bhargava, Franzini and Narendranathan (1982).
} 
and real estate prices. 


\section{References}

Barkham, R. and D. Geltner, "Unsmoothing British Valuation-based Returns Without Assuming an Efficient Market," Journal of Property Research, 1994, vol 11,81-95. Bhargava, A., L. Franzini and W. Narendranathan, "Serial Correlation and Fixed Effects Model," Review of Economic Studies, 1982, vol 49, 533-49.

Fama, E. and K. French, "Permanent and Temporary Components of Stock Prices," Journal of Political Economy, 1988,vol. 96,246-273.

Geltner, D., "Estimating Market Values from Appraised Values Without Assuming an Efficient Market," Journal of Real Estate Research, 1993, vol. 8, 325-345.

Hartzell, D., "Real Estate in the Portfolio," in The Institutional Investor: Focus on Investment Management, ed. F. J. Fabozzi, Ballinger Pub., Cambridge, Mass.

Goetzmann, W., and S. Wachter, "The Global Real Estate Crash: Evidence From an International Database," working paper, Yale School of Management, 1995.

Ibbotson, R., and L. Siegel, "Real Estate Returns: A Comparison with Other Investments," AREUEA Journal, 1984, vol. 12, pp.219-41.

Lim, J., and G. Ong, "Real Estate in an Emerging Financial Market: The Singapore Experience," paper presented at the 1992 AREUEA International Conference on Real Estate and Urban Economics, October, Redondo Beach, CA.

Quan, D., and J. Quigley, "Price Formation and the Appraisal Function in Real Estate Markets," Journal of Real Estate Finance and Economics, Vol 4, No. 2, June, 1991, 127-146.

Shiller, R., "Do Stock Prices Move Too Much to be Justified by Subsequent Changes in Dividents?," American Economic Review, Vol 71, 1981, 421-436. 
Stone, D. and W. Ziemba, "Land and Stock Prices in Japan," Journal of Economic Perspectives, Vol 7, No. 3, Summer, 1993, 149-66.

Worzala, E. and K. Vandell, "Internation Direct Real Estate Investments as Alternative Portfolio Assets for Institutional Investors: An Evaluation," paper presented at the 1993 AREUEA meetings, Anaheim, CA. 
Table 1

Summary Statistics

\section{Countries}

Australia

Capital

Rent

Belgium

Capital

Rent

Canada

Capital

Rent

France

Capital

Rent

Capital

Rent

Hong Kong

Capital

Rent

Italy

Capital

Rent

Indonesia

Capital

Rent

Japan

Capital

Rent

Malaysia

Capital

Rent

Netherland

Capital

Rent

New Zealand

Capital

Rent

Singapore

Capital

Rent

Spain

Capital

Rent

Taiwan

Capital

Rent

U.K.

Capital

Rent

Capital

Rent

\section{Period} (Start Date)

\section{Mean Annual Returns (1988-1994)}

$-2.36$

6.61

$-13.62$

$-14.82$

$-17.15$

6.66

$-18.15$

$-12.31$

4.74

5.03

25.86

20.77

7.49

$-0.59$

29.99

14.42

$-9.43$

$-0.14$

15.66

30.84

3.23

4.14

$-5.61$

$-3.62$

13.21

17.78

0.49

$-1.58$

19.65

6.51

$-3.83$

$-3.62$

$-8.38$

7.35
Autocorrelation

(Full Sample)

.7246

.4716

.8309

.4693

.8428

.2782

.4864

.6188

.6062

.7022

.0377

.1143

.4239

.9865

.3102

.2871

.7878

.6839

.4410

.5854

.3182

.4437

.3222

.5014

.4435

.1130

.6727

.5789

.2995

.2565

.5437

.6639

.8236

1.175 
Table 2

\section{Univariate Regressions: Capital and Rental Values}

Regressed on Stock Returns

(t-statistics in parenthesis)

\begin{tabular}{|c|c|c|c|c|c|c|c|c|}
\hline \multicolumn{5}{|c|}{ Capital } & \multicolumn{4}{|c|}{ Rent } \\
\hline Country & $R^{2}$ & Intercept & Stock & Period & $R^{2}$ & Intercept & Stock & Period \\
\hline "Australia & 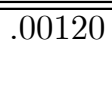 & $\begin{array}{r}2.9493 \\
(0.42872)\end{array}$ & $\begin{array}{c}-0.025562 \\
(-0.098083)\end{array}$ & $\overline{85-94}$ & 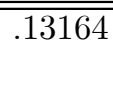 & $\begin{array}{r}6.52970 \\
(27.17207)\end{array}$ & $\begin{array}{r}0.010026 \\
(1.10126)\end{array}$ & 85-94 \\
\hline Belgium & .10512 & $\begin{array}{r}4.42478 \\
(1.21536)\end{array}$ & $\begin{array}{r}0.12265 \\
(1.18729)\end{array}$ & $81-94$ & .00193 & $\begin{array}{r}7.15554 \\
(2.53625)\end{array}$ & $\begin{array}{r}0.012211 \\
(0.15254)\end{array}$ & $81-94$ \\
\hline Canada & .00211 & $\begin{array}{r}-2.30361 \\
(-0.56494)\end{array}$ & $\begin{array}{r}-0.039979 \\
(-0.12168)\end{array}$ & $86-94$ & .08309 & $\begin{array}{r}7.49751 \\
(30.45662)\end{array}$ & $\begin{array}{c}-0.015799 \\
(-0.79650)\end{array}$ & $86-94$ \\
\hline France & .01624 & $\begin{array}{r}7.03324 \\
(1.34879)\end{array}$ & $\begin{array}{r}0.063960 \\
(0.44514)\end{array}$ & $81-94$ & .00108 & $\begin{array}{r}7.87745 \\
(1.97796)\end{array}$ & $\begin{array}{r}0.012501 \\
(0.11391)\end{array}$ & $81-94$ \\
\hline Germany & .00065 & $\begin{array}{r}5.99555 \\
(1.69776)\end{array}$ & $\begin{array}{r}0.0065411 \\
(0.085484)\end{array}$ & $81-94$ & .00492 & $\begin{array}{r}6.41110 \\
(2.46951)\end{array}$ & $\begin{array}{c}-0.013709 \\
(-0.24370)\end{array}$ & $81-94$ \\
\hline Hong Kong & .05827 & $\begin{array}{r}18.97821 \\
(2.09770)\end{array}$ & $\begin{array}{r}0.15934 \\
(0.74630)\end{array}$ & $84-94$ & .11520 & $\begin{array}{r}13.95361 \\
(1.37937)\end{array}$ & $\begin{array}{r}0.25842 \\
(1.08249)\end{array}$ & $81-94$ \\
\hline Italy & .08082 & $\begin{array}{r}8.37021 \\
(1.15552)\end{array}$ & $\begin{array}{r}-0.13596 \\
(-0.88960)\end{array}$ & 84-94 & .00901 & $\begin{array}{r}3.23073 \\
(0.69953)\end{array}$ & $\begin{array}{r}0.027878 \\
(0.28611)\end{array}$ & $84-94$ \\
\hline Indonesia & .00320 & $\begin{array}{r}28.44287 \\
(1.14865)\end{array}$ & $\begin{array}{r}0.026196 \\
(0.12676)\end{array}$ & $88-94$ & .02099 & $\begin{array}{r}8.86686 \\
(0.85086)\end{array}$ & $\begin{array}{r}0.042373 \\
(0.41416)\end{array}$ & $85-94$ \\
\hline Japan & .51633 & $\begin{array}{r}2.17463 \\
(0.31891)\end{array}$ & $\begin{array}{r}1.08041 \\
(3.42676)\end{array}$ & $82-94$ & .00003 & $\begin{array}{r}6.34844 \\
(1.05900)\end{array}$ & $\begin{array}{c}0.0047956 \\
(0.017543)\end{array}$ & 84-94 \\
\hline Malaysia & .04807 & $\begin{array}{r}3.12496 \\
(0.49393)\end{array}$ & $\begin{array}{r}0.13558 \\
(0.77846)\end{array}$ & $81-94$ & .01304 & $\begin{array}{r}13.93237 \\
(1.18458)\end{array}$ & $\begin{array}{r}0.12892 \\
(0.39819)\end{array}$ & $81-94$ \\
\hline Netherland & .10417 & $\begin{array}{r}6.16581 \\
(1.73076)\end{array}$ & $\begin{array}{r}-0.15029 \\
(-1.18126)\end{array}$ & $81-94$ & .12922 & $\begin{array}{l}5.04550 \\
2.60323\end{array}$ & $\begin{array}{r}-0.092368 \\
-1.33447\end{array}$ & $81-94$ \\
\hline New Zealand & .10297 & $\begin{array}{r}-6.85567 \\
(-0.98286)\end{array}$ & $\begin{array}{r}0.16305 \\
(0.75760)\end{array}$ & $88-94$ & .45121 & $\begin{array}{r}-1.70727 \\
(-0.42612)\end{array}$ & $\begin{array}{r}-0.25065 \\
(-2.02753)\end{array}$ & $88-94$ \\
\hline Singapore & .08341 & $\begin{array}{r}17.09217 \\
(1.23661)\end{array}$ & $\begin{array}{r}0.57961 \\
(1.16839)\end{array}$ & $78-94$ & .00765 & $\begin{array}{r}16.01525 \\
1.42861\end{array}$ & $\begin{array}{l}0.13689 \\
0.34023\end{array}$ & $78-94$ \\
\hline Spain & .02882 & $\begin{array}{r}9.28969 \\
(1.01792)\end{array}$ & $\begin{array}{r}0.16582 \\
(0.59676)\end{array}$ & $81-94$ & .00565 & $\begin{array}{r}6.29309 \\
(0.94208)\end{array}$ & $\begin{array}{c}0.053123 \\
(0.26119)\end{array}$ & $81-94$ \\
\hline Taiwan & .38359 & $\begin{array}{r}9.00045 \\
(0.58105)\end{array}$ & $\begin{array}{r}0.46156 \\
(1.76393)\end{array}$ & $88-94$ & .34058 & $\begin{array}{r}1.60371 \\
(0.20473)\end{array}$ & $\begin{array}{r}0.21264 \\
(1.60699)\end{array}$ & $88-94$ \\
\hline U.K. & .00009 & $\begin{array}{r}6.63146 \\
(0.82417)\end{array}$ & $\begin{array}{r}-0.011321 \\
(-0.034187)\end{array}$ & $81-94$ & .00117 & $\begin{array}{r}5.49802 \\
(0.81435)\end{array}$ & $\begin{array}{r}0.033025 \\
(0.11885)\end{array}$ & $81-94$ \\
\hline U.S. & .00211 & $\begin{array}{r}-1.07374 \\
(-0.27715)\end{array}$ & $\begin{array}{r}0.043187 \\
(0.17235)\end{array}$ & $79-94$ & .13822 & $\begin{array}{r}7.68415 \\
(20.25164)\end{array}$ & $\begin{array}{c}-0.032218 \\
(-1.26644)\end{array}$ & $83-94$ \\
\hline
\end{tabular}


Table 3a

Capital Values
Time Series Regression Results - With Lagged Real Estate and Stocks

(t-statistics in parenthesis)

(F-statistic is test for joint significance of the stock and lagged stock variable)

\begin{tabular}{|l|l|r|r|r|r|r|c|}
\hline Country & $R^{2}$ & Intercept & Stock & Capital(-1) & Stock(-1) & F-Statistic & Period \\
\hline \hline Australia & \multicolumn{1}{|c}{.6845} & -7.8218 & .0933 & .7400 & .3416 & 1.133 & $86-94$ \\
& & $(-1.0523)$ & $(.4264)$ & $(2.9788)$ & $(1.4881)$ & & \\
\hline Belgium & .7473 & -4.0189 & .1161 & .7523 & .0885 & 2.417 & $82-94$ \\
& & $(-1.3507)$ & $(1.8313)$ & $(4.0749)$ & $(1.3083)$ & & \\
\hline Canada & .7196 & -5.0479 & .1799 & .9258 & .2843 & 0.266 & $87-94$ \\
& & $(-.9534)$ & $(.4683)$ & $(3.1024)$ & $(.7139)$ & & \\
\hline France & .6103 & -7.1568 & .1703 & .4499 & .3029 & 4.323 & $82-94$ \\
& & $(-1.3829)$ & $(1.6034)$ & $(2.1527)$ & $(2.8037)$ & & \\
\hline Germany & .4055 & -6.0098 & .0589 & .6588 & .0528 & 0.502 & $82-94$ \\
& & $(-.1353)$ & $(.8218)$ & $(2.3928)$ & $(.7560)$ & & \\
\hline Hong Kong & .0573 & 20.8809 & .1379 & .0774 & -.0187 & 0.177 & $85-94$ \\
& & $(1.13736)$ & $(.5039)$ & $(.2052)$ & $(-.0601)$ & & \\
\hline Italy & .2666 & 1.2227 & -.0874 & .4740 & .1281 & 0.428 & $85-94$ \\
& & $(.1169)$ & $(-.5061)$ & $(1.1827)$ & $(.7183)$ & & \\
\hline Indonesia & .9208 & -21.3371 & .2982 & .4317 & .4214 & 10.474 & $89-94$ \\
& & $(-1.3163)$ & $(1.3355)$ & $(1.9599)$ & $(4.3670)$ & & \\
\hline Japan & .7007 & -3.0511 & .6382 & .5038 & .0664 & 1.706 & $83-94$ \\
& & $(-.4555)$ & $(1.8407)$ & $(1.5429)$ & $(.1565)$ & & \\
\hline Malaysia & .3321 & -2.9641 & .1909 & .4072 & .1638 & 0.892 & $82-94$ \\
& & $(-.4235)$ & $(1.1256)$ & $(1.4749)$ & $(.9052)$ & & \\
\hline Netherland & .3171 & -.2852 & -.0709 & .4345 & .1925 & 1.443 & $82-94$ \\
& & $(-.0509)$ & $(-.5119)$ & $(1.4400)$ & $(1.3227)$ & & \\
\hline New Zealand & .8833 & -17.9878 & .3856 & -.2496 & .5357 & 6.795 & $89-94$ \\
& & $(-2.9212)$ & $(2.6596)$ & $(-.8242)$ & $(3.4457)$ & & \\
\hline Singapore & .5217 & -4.5499 & 1.0212 & .4007 & .8657 & 4.072 & $79-94$ \\
& & $(-.3437)$ & $(2.3848)$ & $(1.9117)$ & $(2.0283)$ & & \\
\hline Spain & .6621 & -7.5546 & .1656 & .5933 & .4569 & 2.845 & $82-94$ \\
& & $(-.9849)$ & $(.8299)$ & $(3.0039)$ & $(2.3117)$ & & \\
\hline Taiwan & .5666 & -6.3936 & .3376 & .3141 & .0724 & 0.840 & $89-94$ \\
& & $(-.3994)$ & $(1.2964)$ & $(.7902)$ & $(.2438)$ & & \\
\hline U.K. & .5919 & -15.0421 & .3960 & .5910 & .5353 & 2.869 & $82-94$ \\
& & $(-1.8243)$ & $(1.6153)$ & $(2.8588)$ & $(2.1650)$ & & \\
\hline U.S. & .7471 & -.03262 & -.0913 & .8428 & -.0003 & 0.218 & $80-94$ \\
& & $(-.0095)$ & $(-.6156)$ & $(5.6682)$ & $(-.0024)$ & & \\
\hline
\end{tabular}


Table 3b

\section{Rental Values}

Time Series Regression Results - With Lagged Real Estate and Stocks (t-statistics in parenthesis)

(F-statistic is test for joint significance of the stock and lagged stock variable)

\begin{tabular}{|l|l|r|r|r|r|r|c|}
\hline Country & \multicolumn{1}{|c|}{$R^{2}$} & Intercept & Stock & Rent(-1) & Stock(-1) & F-Statistic & Period \\
\hline \hline Australia & .3962 & 3.3521 & .0143 & .4548 & .0055 & 0.806 & $86-94$ \\
& & $(1.1155)$ & $(1.2608)$ & $(.9466)$ & $(.3572)$ & & \\
\hline Belgium & .2807 & 1.0816 & .0017 & .4872 & .0848 & 0.552 & $82-94$ \\
& & $(.2570)$ & $(.0220)$ & $(1.5951)$ & $(1.0507)$ & & \\
\hline Canada & .4571 & 3.7826 & .0241 & .4222 & .0538 & 1.563 & $87-94$ \\
& & $(.8308)$ & $(.7066)$ & $(.6954)$ & $(1.5849)$ & & \\
\hline France & .4897 & -1.2995 & -.0075 & .6426 & .1375 & 1.177 & $82-94$ \\
& & $(-.2842)$ & $(-.0767)$ & $(2.4837)$ & $(1.4563)$ & & \\
\hline Germany & .4791 & -1.0093 & .0295 & .7694 & .0509 & 0.588 & $82-94$ \\
& & $(-.2857)$ & $(.5885)$ & $(2.8050)$ & $(1.0355)$ & & \\
\hline Hong Kong & .1931 & 7.0231 & .3477 & .3126 & .0022 & 0.666 & $85-94$ \\
& & $(.3433)$ & $(1.0775)$ & $(.7776)$ & $(.0064)$ & & \\
\hline Italy & .8152 & -5.8085 & .0591 & .9899 & .0853 & 2.019 & $85-94$ \\
& & $(-1.9013)$ & $(1.1501)$ & $(4.7182)$ & $(1.6674)$ & & \\
\hline Indonesia & .6808 & -9.6700 & .1142 & .3849 & .2120 & 4.652 & $86-94$ \\
& & $(-.9241)$ & $(1.3978)$ & $(1.3861)$ & $(2.8449)$ & & \\
\hline Japan & .9400 & -4.2237 & -.3254 & .7477 & .6713 & 28.853 & $85-94$ \\
& & $(-1.9713)$ & $(-3.6510)$ & $(6.5436)$ & $(7.5709)$ & & \\
\hline Malaysia & .4306 & -2.1687 & .1435 & .5495 & .3304 & 0.651 & $82-94$ \\
& & $(-.1782)$ & $(.4995)$ & $(2.1806)$ & $(1.1044)$ & & \\
\hline Netherland & .3961 & -.0420 & -.0389 & .5775 & .1035 & 1.527 & $82-94$ \\
& & $(-.0124)$ & $(-.5292)$ & $(1.9386)$ & $(1.3117)$ & & \\
\hline New Zealand & .8459 & -7.4790 & .2696 & 1.768 & .5609 & 3.335 & $89-94$ \\
& & $(-1.8746)$ & $(1.1857)$ & $(2.4185)$ & $(2.1026)$ & & \\
\hline Singapore & .4048 & .0511 & .4105 & .0981 & .9980 & 3.956 & $79-94$ \\
& & $(.0044)$ & $(1.0918)$ & $(.4249)$ & $(2.7752)$ & & \\
\hline Spain & .6213 & -5.6473 & .0380 & .5487 & .3961 & 3.489 & $82-94$ \\
& & $(-.9644)$ & $(.2469)$ & $(2.6149)$ & $(2.6416)$ & & \\
\hline Taiwan & .5859 & -5.9910 & .2291 & .2443 & .1322 & 1.189 & $89-94$ \\
& & $(-.6306)$ & $(1.3962)$ & $(.5036)$ & $(.7728)$ & & \\
\hline U.K. & .6464 & -11.8197 & .3323 & .7183 & .4005 & 2.445 & $82-94$ \\
& & $(-1.6805)$ & $(1.6167)$ & $(3.5976)$ & $(1.9246)$ & & \\
\hline U.S. & .6838 & -1.2419 & -.0016 & 1.1827 & .0093 & 0.121 & $84-94$ \\
& & $(-.4559)$ & $(-.0712)$ & $(3.3743)$ & $(.4293)$ & & \\
\hline
\end{tabular}


Table 4a

\section{Fixed Effect Estimation For all 17 Countries Capital Returns as Dependent Variable 1979-1994}

$\begin{array}{lrrlrr}\text { Variable } & \text { Coefficient } & \text { t-statistic } & \text { Variable } & \text { Coefficient } & \text { t-statistic } \\ \text { Intercept } & -19.7940 & -2.7580 & \text { Australia } & 5.2908 & .6647 \\ \text { Stock } & .2293 & 3.7099 & \text { Belgium } & 5.7333 & .7991 \\ \text { Capital(-1) } & .3387 & 5.4664 & \text { Canada } & 6.3921 & .7744 \\ \text { Stock(-1) } & .2899 & 5.7945 & \text { France } & 6.6566 & .9284 \\ 79 & 17.1736 & 1.1950 & \text { Germany } & 6.2944 & .8790 \\ 80 & 59.5690 & 4.8142 & \text { Hong Kong } & 15.6126 & 1.9593 \\ 81 & 42.4252 & 3.3028 & \text { Italy } & 4.8016 & .6197 \\ 82 & -3.2786 & -.3997 & \text { Indonesia } & 10.0384 & 1.0073 \\ 83 & 8.1862 & 1.0328 & \text { Japan } & 13.8362 & 1.8744 \\ 84 & 10.4049 & 1.3050 & \text { Malaysia } & 5.2158 & .7774 \\ 85 & 10.4049 & 1.3050 & \text { Netherlands } & 6.1328 & .8613 \\ 86 & 4.4191 & .61725 & \text { New Zealand } & 15.1947 & 2.1242 \\ 87 & 16.1876 & 2.3247 & \text { Singapore } & 18.7910 & 2.7403 \\ 88 & 25.7869 & 3.3727 & \text { Spain } & 11.8063 & 1.6451 \\ 89 & 10.7063 & 1.5385 & \text { Taiwan } & 12.6092 & 1.3986 \\ 90 & 4.9973 & .72382 & \text { U.K. } & 7.1188 & .9998 \\ 91 & 3.2549 & .4374 & & & \\ 92 & .3559 & .0531 & \text { R-Square } & .6163 & \\ 93 & -4.1594 & -.5300 & & & \end{array}$

F-test for joint significance of time effect: 4.114047 with $(15,165)$ degrees of freedom.

F-test for joint significance of country effect: 0.852021 with $(16,165)$ degrees of freedom. 
Table $4 \mathrm{~b}$

\section{Fixed Effect Estimation For all 17 Countries Rental Returns as Dependent Variable 1979-1994}

$\begin{array}{lrrlrr}\text { Variable } & \text { Coefficient } & \text { t-statistic } & \text { Variable } & \text { Coefficient } & \text { t-statistic } \\ \text { Intercept } & -4.3287 & -.6134 & \text { Australia } & -2.9342 & -.3711 \\ \text { Stock } & .1108 & 2.4662 & \text { Belgium } & -4.5849 & -.6332 \\ \text { Rent(-1) } & .2593 & 3.8012 & \text { Canada } & .2309 & .0282 \\ \text { Stock(-1) } & .2038 & 4.4892 & \text { France } & -3.9722 & -.5494 \\ 79 & 30.7466 & 2.6796 & \text { Germany } & -4.9381 & -.6823 \\ 80 & 13.0210 & 1.0906 & \text { Hong Kong } & 5.6334 & .7241 \\ 81 & 52.3411 & 4.5249 & \text { Italy } & -7.5806 & -.9861 \\ 82 & 12.6333 & 1.6236 & \text { Indonesia } & -10.6041 & -1.4703 \\ 83 & 6.5937 & .8416 & \text { Japan } & -1.8106 & -.2361 \\ 84 & -2.6681 & -.3787 & \text { Malaysia } & 2.0566 & .2935 \\ 85 & 7.1195 & .9996 & \text { Netherlands } & -5.9397 & -.8215 \\ 86 & 2.4529 & .3777 & \text { New Zealand } & -.5881 & -.0817 \\ 87 & 12.6834 & 1.9973 & \text { Singapore } & 2.6729 & .3819 \\ 88 & 19.9547 & 2.7773 & \text { Spain } & -2.9187 & -.4046 \\ 89 & 15.2882 & 2.3576 & \text { Taiwan } & -4.9551 & -.5787 \\ 90 & 9.7374 & 1.4879 & \text { U.K. } & -4.1014 & -.5684 \\ 91 & 5.9246 & .8362 & & & \\ 92 & -1.6001 & -.2523 & \text { R-Square } & .4565 & \\ 93 & -2.4822 & -.3497 & & & \end{array}$

F-test for joint significance of time effect: 3.5590 with $(15,169)$ degrees of freedom. F-test for joint significance of country effect: 0.6170 with $(16,169)$ degrees of freedom. 
Table 5a

\section{Fixed Effect Model - Europe Capital Returns as Dependent Variable}

$\begin{array}{lrrlrr}\text { Variable } & \text { Coefficient } & \text { t-statistic } & \text { Variable } & \text { Coefficient } & \text { t-statistic } \\ \text { Intercept } & -.4234 & -.0635 & 89 & & \\ \text { Stock } & -.0453 & -.5311 & 90 & .6701 & .8065 \\ \text { Capital(-1) } & .4531 & 3.9958 & 91 & -13.5701 & -1.5722 \\ \text { Stock(-1) } & .1508 & 1.7964 & 92 & -15.5494 & -2.1395 \\ 82 & -7.3098 & -.9219 & 93 & -2.4961 & -.2973 \\ 83 & 7.5385 & .9324 & \text { Belgium } & .6047 & .1204 \\ 84 & -1.6442 & -.2134 & \text { France } & .7335 & .1465 \\ 85 & 9.7888 & .9811 & \text { Germany } & .9267 & .1856 \\ 86 & .9106 & .1020 & \text { Italy } & -.1716 & -.0316 \\ 87 & 5.6711 & .7381 & \text { Netherland } & .0314 & .0063 \\ 88 & 13.9417 & 1.5862 & \text { Spain } & 3.6872 & .7331 \\ & & & & & \end{array}$

F-test for joint significance of time effect: 2.509381 with $(12,66)$ degrees of freedom.

F-test for joint significance of country effect: 0.134579 with $(6,66)$ degrees of freedom.

Table 5b

Fixed Effect Model - Asia

Capital Returns as Dependent Variable

$\begin{array}{lrrlrr}\text { Variable } & \text { Coefficient } & \text { t-statistic } & \text { Variable } & \text { Coefficient } & \text { t-statistic } \\ & & & & & \\ \text { Intercept } & -21.2445 & -1.8165 & 87 & 21.2118 & 1.7149 \\ \text { Stock } & .5317 & 4.8842 & 88 & 34.5931 & 2.5783 \\ \text { Capital(-1) } & .3065 & 3.6552 & 89 & 12.1162 & 1.0391 \\ \text { Stock(-1) } & .3904 & 5.2352 & 90 & 11.9225 & .9909 \\ 79 & 27.0571 & 1.5124 & 91 & 17.2987 & 1.3276 \\ 80 & 82.5639 & 4.4598 & 92 & 13.4520 & 1.1439 \\ 81 & 65.4936 & 3.3670 & 93 & -19.4088 & -1.2736 \\ 82 & -2.3394 & -.1397 & \text { Australia } & -3.9714 & -.3924 \\ 83 & 11.4671 & .7715 & \text { Indonesia } & -4.3482 & -.3748 \\ 84 & 9.0498 & .6566 & \text { Japan } & 5.4171 & .5695 \\ 85 & 35.4635 & 2.6030 & \text { Malaysia } & -5.8726 & -.6269 \\ 86 & 15.0230 & 1.1245 & \text { New Zealand } & 7.5568 & .7975 \\ & & & \text { Singapore } & 8.2637 & .9008 \\ \text { R-Square } & .742133 & & \text { Taiwan } & 2.1773 & .2027\end{array}$

F-test for joint significance of time effect: 3.928243 with $(15,63)$ degrees of freedom.

F-test for joint significance of country effect: 0.8041588 with $(7,63)$ degrees of freedom. 
Table 5c

\section{Fixed Effect Model - Europe Rental Returns as Dependent Variable}

$\begin{array}{lrrlrr}\text { Variable } & \text { Coefficient } & \text { t-statistic } & \text { Variable } & \text { Coefficient } & \text { t-statistic } \\ \text { Intercept } & -2.5035 & -.5028 & 89 & & \\ \text { Stock } & -.0281 & -.4552 & 90 & 3.8333 & 1.0415 \\ \text { Rent(-1) } & .4665 & 4.2531 & 91 & -1.8886 & .6612 \\ \text { Stock(-1) } & .1203 & 1.9847 & 92 & -5.8433 & -1.0786 \\ 82 & 1.7492 & -.2965 & 93 & -4.8637 & -.7937 \\ 83 & 7.2269 & 1.1833 & \text { Belgium } & .3159 & .0861 \\ 84 & 1.2469 & .2157 & \text { France } & .3697 & .1011 \\ 85 & 13.1127 & 1.7912 & \text { Germany } & .0174 & .0048 \\ 86 & 1.5997 & .2374 & \text { Italy } & -2.2863 & -.5792 \\ 87 & 9.1431 & 1.5453 & \text { Netherland } & -.9325 & -.2571 \\ 88 & 10.7748 & 1.6015 & \text { Spain } & .7380 & .2036 \\ & & & & & \end{array}$

F-test for joint significance of time effect: 2.01448 with $(12,66)$ degrees of freedom. F-test for joint significance of country effect: 0.133449 with $(6,66)$ degrees of freedom.

\section{Table 5d}

Fixed Effect Model - Asia Rental Returns as Dependent Variable

$\begin{array}{lrrlrr}\text { Variable } & \text { Coefficient } & \text { t-statistic } & \text { Variable } & \text { Coefficient } & \text { t-statistic } \\ \text { Intercept } & -1.1015 & -.0844 & 87 & & \\ \text { Stock } & .1322 & 1.6735 & 88 & 11.6309 & .8916 \\ \text { Rent(-1) } & .1621 & 1.4617 & 89 & 27.2995 & 1.8367 \\ \text { Stock(-1) } & .2198 & 2.7352 & 90 & 28.1503 & 2.1874 \\ 79 & 35.1372 & 2.0183 & 91 & 15.5245 & 1.1244 \\ 80 & 19.1595 & 1.0316 & 92 & 9.7772 & .6659 \\ 81 & 56.8521 & 3.2089 & 93 & -2.3288 & -.1771 \\ 82 & 29.5457 & 1.6886 & \text { Australia } & -2.2595 & -.1505 \\ 83 & 9.8016 & .5685 & \text { Indonesia } & -17.7408 & -.8648 \\ 84 & -10.0894 & -.6474 & \text { Japan } & -7.8221 & -1.7372 \\ 85 & 8.2016 & .5649 & \text { Malaysia } & -3.6893 & -.3654 \\ 86 & 6.9396 & .4992 & \text { New Zealand } & -6.7505 & -.6423 \\ & & & \text { Singapore } & -3.2773 & -.3239 \\ \text { R-Square } & .47661 & & \text { Taiwan } & -12.0340 & -.9967\end{array}$

F-test for joint significance of time effect: 1.9587 with $(15,71)$ degrees of freedom.

F-test for joint significance of country effect: 0.6686 with $(7,71)$ degrees of freedom. 